\title{
Assessing Forest Classification in a Landscape-Level Framework: An Example from Central European Forests
}

\author{
Antonín Kusbach ${ }^{1, *}$, Michal Friedl ${ }^{1}$, Václav Zouhar ${ }^{2}$, Tomáš Mikita ${ }^{3}$ and Jan Šebesta ${ }^{1}$ \\ 1 Department of Forest Botany, Dendrology and Geobiocoenology, Faculty of Forestry and Wood Technology, \\ Mendel University in Brno, Zemědělská 3, 61300 Brno, Czech Republic; \\ michal.friedl@email.cz (M.F.); sebestian.cz@gmail.com (J.Š.) \\ 2 Forest Management Institute, Brandýs nad Labem, Branch Brno, Vrázova 1, 61600 Brno, Czech Republic; \\ zouhar.vaclav@uhul.cz \\ 3 Department of Forest Management and Applied Geoinformatics, Faculty of Forestry and Wood Technology, \\ Mendel University in Brno, Zemědělská 3, 61300 Brno, Czech Republic; tomas.mikita@mendelu.cz \\ * Correspondence: kusbach@mendelu.cz
}

Academic Editors: Kevin L. O’Hara and Timothy A. Martin

Received: 31 August 2017; Accepted: 16 November 2017; Published: 23 November 2017

\begin{abstract}
Traditional land classifications developed on the basis of what was once prevailing expert knowledge have since largely become obsolete. We assessed expert knowledge based landscape-level units delineated in central European temperate forests: Natural Forest Areas (NFA) and Forest Vegetation Zones (FVZ). Our focus was determining to what degree these units reflect vegetation-environmental relationships. After considering as many as 49,000 plots with vegetation and 25,000 plots with environmental data within a territory of the Czech Republic, we analyzed 11,885 plots. We used multivariate statistics to discriminate between the landscape-level units. While NFAs performed extremely well, FVZ results were less successful. Classification of the environment provided better results than classification of vegetation for both the Hercynicum and Carpaticum phytogeographic part of the Czech Republic. Taking into account significance of the environment in our analysis, a delimitation of FVZs and similar vegetation-driven structures worldwide via explicit a priori stratification by tree species without consideration of environmental limits would not be supported by our analysis. We suggest not relying only on vegetation in classification analyses, but also including the significant environmental factors for direct classification of FVZ and units in particular in altered vegetation composition setting such as the central European forests. We propose a novel interpretation of FVZ via appropriate vegetation stratification throughout the environment used in conjunction with the zonal concept. Understanding of coarse-scaled vegetation-environmental relationships is not only fundamental in forest ecology and forest management, but is also essential for improving lower classification levels. Valuable expert knowledge should be combined with formal quantification, which is consistent with recent calls for advanced multidisciplinary ecological classifications in Europe and North America and for forming classifications in Asia.
\end{abstract}

Keywords: ecological land classification; forest classification; forest vegetation zone; natural forest area; potential natural vegetation; vegetation zonation; zonal concept

\section{Introduction}

As a distinctive land feature, vegetation has been a leading component of traditional ecological classifications [1,2]. The concept of potential natural vegetation (PNV) sensu Tüxen [3] fostered the 
establishment of European and North American land classifications (e.g., [4-12]). This relatively complex approach launched a new line of research: ecological land assessment introduced e.g., in a special issue of the Journal of Forestry, October 1978. These 'eastern' and 'western' classification systems reflected trends in environmental sciences at that time and incorporated, concepts such as forest type [13], phytosociology [14], ecosystem, polyclimax [15] and biogeocoenology [16].

Within classification systems, coarse-scale, landscape-level units are important for fine-scale, lower units, and vice versa, one example being a top-down and bottom-up approach wherein the spatial-functional hierarchy of large land segments are considered [17-19]. Top-down based frameworks were established regionally throughout Europe for the purposes of forestry practice and landscape management, for example Zlatník [20] in Slovakia, Plíva and Žlábek [21] in the Czech Republic, Kilian et al. [22] in Austria, Dahdouh-Guebas et al. [23] in Belgium, Blasi et al. [24] in Italy, Gauer and Aldinger [25] in Germany, but also in North America [12,26]. These national systems vary in their specific criteria for defining site types, but in general, they share a fundamental focus on depicting the variation in topography, substrate and vegetation characteristics across the landscape for supporting decisions relevant to forestry [27]. A combined top-down and bottom-up approach was applied in the Biogeoclimatic Ecosystem Classification (BEC) in British Columbia (BC) [11], its 'sister' system in Great Britain [28], in Ireland [29] and generalized an idea of 'forest type' in the Czech Forest Ecosystem Classification [30].

These ecological classification systems based on expert knowledge relevant at the time have neither been updated nor have they ever been formally quantified with contemporary analytical methods. Landscape ecologists, biogeographers and conservationists alike have gradually considered these systems unreliable, as they have essentially become obsolete [31]. Forest ecologists and practical foresters argue about correct and identical field categorization. We have personally witnessed a criticism of the classification system for its superfluous particularity at a number of meetings in the last decade. We appeal to clarification of this system for researchers, managers and forest owners to minimize issues in application of the system. Except attempts such as Kupfer and Franklin [32], DeLong et al. [33], rigorous quantification of extensive data of both vegetation and the environment does not currently exist [34]. We took advantage of the Database of Czech Forest Ecosystem Classification where various vegetation, environmental, soil properties, and forest management data are available.

Forest managers must have an ecological land classification system in order to manage efficiently. In this study, we assessed expert knowledge based landscape-level units represented by Natural Forest Areas (NFAs) and Forest Vegetation Zones (FVZs) used in forest ecology and related fields in the Czech Republic. We inspected the relevance of these units selected not only for their theoretical importance, but also for their practical involvement in forest ecosystem management. We used available vegetation, environmental data and a soil designation to assess landscape-level units, to identify their potential drawbacks and to suggest a potential solution. The objectives of this study were (i) to determine if vegetation and environmental conditions are related to ecological land classification; (ii) to explore correct differentiating of FVZ and NFA based on vegetation and environmental factors; and (iii) to develop a novel interpretation of FVZ via a proper stratification of vegetation throughout the environment. This study can facilitate minimizing problems in application of the system in the future by providing more unit-specific ecological information.

\section{Materials and Methods}

\subsection{Fundamentals of the Czech Forest Ecosystem Classification}

The Czech Forest Ecosystem Classification (CFEC) has served as a national standard for forestry for almost 50 years [35]. It was introduced in 1971 based on a subjective sampling design meaning that plots used for data observations and measurements have been purposefully selected. This means that plots are selected based on expert knowledge and giving preference to areas with mature 
and close-to-natural vegetation corresponding to the system's central concept of PNV. The system consists of three hierarchical levels: superstructure, basic, and lower (Figure 1). Superstructure NFAs (Figure 1a) were delineated using a top-down approach to be as homogeneous as possible according to geologic, geomorphologic and overall climatic differences [21]. These are considered the top administrative units within the Czech forestry hierarchy, which drive strategic planning [36]. The NFA concept is similar to the Ecological Regions developed by Bailey [12] in the United States.

The FVZs used in this study are numbered 1 through 9: (1) Quercus, (2) Fagus-Quercus, (3) Quercus-Fagus, (4) Fagus, (5) Abies-Fagus, (6) Picea-Fagus, (7) Fagus-Picea, (8) Picea, (9) Pinus mugo (Figure 1b for FVZs 3-5. See also Machar et al. [37]) [20,30]. They have represented the most important ecological framework for both basic and lower CFEC units, forest management guidelines [38] and state legislation. For each FVZ, potential natural vegetation [3], expressed by climax tree species is an indirect classifier of macroclimatic (altitudinal) and mesoclimatic (local topographic-slope aspect, climate inversions) conditions (e.g., [39]). Forest Vegetation Zones represents a natural community affected by macro and mesoclimate changes [40]. The original FVZ concept links both altitudinal and topographic climate, and thus considers their combined effect on vegetation. While altitudinal changes of environmental factors are relatively well known, local topography, often combined with soil peculiarities, represents a set of complex moisture changes. As a result, FVZs have been mapped as zonal, spatially homogeneous areas driven by macroclimate (Figure 1b), and azonal segments (warmer/drier or cooler/wetter than zonal, nested inside the zonal FVZs) scattered in a landscape driven by mesoclimate (Figure 1c).

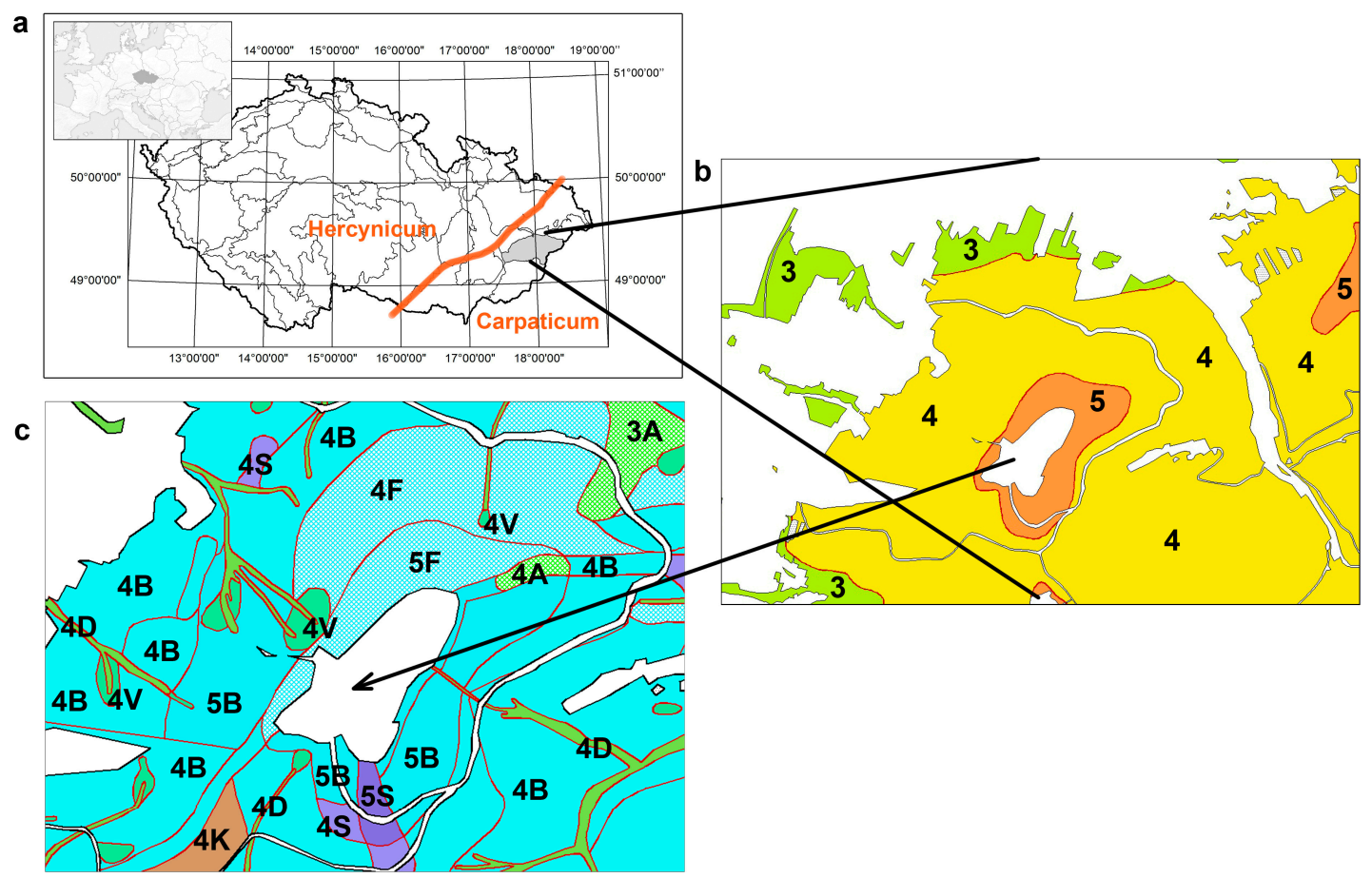

Figure 1. The level scheme of the Czech Forest Ecosystem Classification. (a) Distribution of Natural Forest Areas (NFAs) within the Czech Republic. The NFA No 41 within the Carpaticum phytogeographic region is shadowed. (b) A map of Forest Vegetation Zones (FVZ). Zooming into the NFA No 41 reveals the FVZs 3-5. (c) A classification (forest typological) map. Additional zooming shows the classification map with applied units of the system (Forest Site Complexes [35]) designated by figures (relevant to FVZ) and letters (edaphic categories). The lower units are not shown. Within a zone, an azonal element can appear, e.g., FVZ 3, 4 (Forest Site Complexes 3A, 4A) within the zonal FVZ 4, 5. These azonal sites follow exposed ridges with a skeletal soil. See the Methods for explanation of the system structure. 
Basic and lower level units (especially Forest Site Complexes [35]) has been serving as an ecological framework for Management Complexes, units for forest management differentiation. A framework structure of forest management built on such units makes management recommendations standardized across all types of a forest ownership within the Czech Republic. Besides forestry, the CFEC system units serve e.g., in a sector of nature conservation in detailed site mapping, economic sector for evaluation of a forestland, in soil conservation activities (erosion, landslides after recent frequent extreme run-offs), and other fields where ecological information on forests is needed.

The level scheme has not changed since the CFEC was established in 1971. Except for general assessment of system units [41], these units have not been tested for ecological correctness, i.e., how these units are robust in reflection of vegetation-environmental relationships and how they are able to differentiate between environmental conditions. This system has frequently been criticized for being overly detailed and making practical management more difficult than it should be. In a formal critique, it was suggested that the system be revised [42-45]. The structure of the CFEC is not systematic and the system is obsolete [44,46,47]. For example, forest managers, practical foresters, nature conservators together with botanists argue about the identical field categorization. In the system, attributes of each unit such as FVZ is supposed to be the same across the territory, which it is designated for. This is not a case of CFEC. A vague structure of FVZ brings troubles not only into forest management structuring but also to forest genetics, and distribution and use of reproductive material such as seeds, seedlings and propagules. It applies also for use of the system units in other sectors already mentioned.

\subsection{Data}

The Czech forest classification system database [48], managed by the Forest Management Institute, contains almost 49,000 vegetation records and over 25,000 environmental and soil observations and measurements collected throughout the country $\left(78,000 \mathrm{~km}^{2}\right)$ since 1950 's until 2007. Due to the subjective sampling design (explained above), there is no regular distribution of sampling plots within the Czech territory. Standards of establishment has changed minimally during a time. A plot $\left(500 \mathrm{~m}^{2}\right.$ circle) can contain up to three inspections. We used the latest vegetation and environmental description in our analysis, so there were no replicates of plots in the analysis. We eliminated habitats that were represented by less than ten plots, and plots without climatic data. We checked the data for correctness and completeness, e.g., for extreme outliers (Standard Deviation > 5). After this preparation, we used 11,885 plots with vegetation and environmental data for following analytical steps.

\subsubsection{Environmental and Soil Data}

For each sample plot, we calculated common geomorphic indices using a Digital Terrain Model created on a Digital Relief Model of 4th Generation (Table 1). The Digital Relief Model was generalized with Airborne Laser Scanning of the Czech Republic in 2009-2013 that was measured at a $5 \times 5 \mathrm{~m}$ resolution [49]. We resampled this dataset to create a coarser $10 \times 10 \mathrm{~m}$ pixel resolution to achieve: (1) a feasible compromise between the geographical extent of the landscape-level units considered and a grain (a pixel size) characterizing an appropriate level of detail of terrain topography, and (2) faster calculation of the indices. Our aim was to filter out microsites (different microclimate or soil moisture conditions). A description of indices suitable for detecting typical topographic characteristics is available in Supplementary Material A. The slope aspect in azimuth degrees measured in the field was corrected for the magnetic declination and converted for aspect value $(a v)$ to the scale $0-1$ as a measure of radiation [50]. Soil properties were assessed via designation to soil types and subtypes [51] (Table 1). 
Table 1. Types of environmental factors used in the study analysis.

\begin{tabular}{|c|c|c|c|}
\hline Climatic Factors & Character & Abbreviation & Units/Values \\
\hline Annual total precipitation & $\mathrm{R}$ & Syr & $\mathrm{mm}$ \\
\hline Annual mean temperature & $\mathrm{D}$ & Tyr & ${ }^{\circ} \mathrm{C}$ \\
\hline $\begin{array}{l}\text { Monthly mean precipitation } \\
\text { (January-December) }\end{array}$ & $\mathrm{D}$ & S01-S12 & $\mathrm{mm}$ \\
\hline $\begin{array}{l}\text { Monthly mean temperature } \\
\text { (January-December) }\end{array}$ & $\mathrm{D}$ & T01-T12 & ${ }^{\circ} \mathrm{C}$ \\
\hline Vegetation period $10^{\circ} \mathrm{C}$ & I & V10 & days \\
\hline Vegetation period $8{ }^{\circ} \mathrm{C}$ & $\mathrm{I}$ & V8 & days \\
\hline \multicolumn{4}{|l|}{ Physiographic/geomorphic factors } \\
\hline Altitude & I & alt & meters \\
\hline Slope gradient & I & slope & degrees \\
\hline Slope aspect value & I & av & values $0-1[50]$ \\
\hline Topographic exposure & I & Topex & values $0-255$ \\
\hline Mass Balance Index & I & MBI & values $-0.7-2$ \\
\hline Positive Openness & I & $\mathrm{PO}$ & values $0-2$ \\
\hline Topography Wetness Index & I & TWI & values $0-26$ \\
\hline Saga Wetness Index & I & SAGA & values $0-12$ \\
\hline Topographic Position Index & I & TPI & values $-11.9-12$ \\
\hline Terrain Roughness Index & I & TRI & values $0-60$ \\
\hline Solar Radiation & I & Solrad & values $635,000-1,400,000$ \\
\hline $\begin{array}{c}\text { Vertical Distance to Channel } \\
\text { Network }\end{array}$ & I & VertD & values $0-762$ \\
\hline Convergence Index & I & $\mathrm{CI}$ & values $-87-89$ \\
\hline Relative slope position & I & RSP & values $0-1$ \\
\hline Valley depth & I & VD & meters / 0-600 \\
\hline $\begin{array}{l}\text { Terrain Classification Index for } \\
\text { lowlands }\end{array}$ & I & TCIlow & values $0-1$ \\
\hline Gradient & I & Grad & values $0-1$ \\
\hline Gradient Difference & I & GradD & values $-0.5-0.3$ \\
\hline Normalized Height & I & HNO & values $0-1$ \\
\hline Slope Height & I & $\mathrm{SH}$ & meters $/ 0-450$ \\
\hline Diurnal Anisotropic Heating & I & Diur & values $-0.6-0.5$ \\
\hline Texture & I & Texture & values $0-0.9$ \\
\hline Local convexity & I & Convex & values $0-0.8$ \\
\hline Standardized Height & I & HST & meters $/ 0-1500$ \\
\hline \multicolumn{4}{|l|}{ Geologic/Soil Factors } \\
\hline Geology & I & geol & NA, categorical \\
\hline Soil substrate & $\mathrm{R}$ & substr & $\mathrm{NA}$, categorical \\
\hline Soil type & $\mathrm{R}$ & stype & $\mathrm{NA}$, categorical \\
\hline Soil subtype & $\mathrm{R}$ & ssubtype & $\mathrm{NA}$, categorical \\
\hline
\end{tabular}

Note: D—direct factor; I-indirect factor; R—resource factor (Austin and Smith 1989).

\subsubsection{Climatic Data}

We assigned climate data for each Forest Management Institute sampling plot location by overlaying the plot coordinates with the Czech Hydrometeorological Institute gridded data. We used 1961-1990 weather station records (the 2nd Climatic Normal) and extrapolations of mean temperature, mean precipitation and two vegetation periods (a sum of days with mean temperature $>8$ and $10^{\circ} \mathrm{C}$ ) [52] (Table 1$)$.

\subsubsection{Vegetation Data}

We used a vegetation description of woody, herbaceous and graminoid species abundances in eight layers from seedlings up to overstory trees [40]. We excluded bryophytes, lichens and all invasive species [53]. All subtypes were compiled into species-level aggregates. In total, 1508 species and aggregates were used. 
The structure of mid-European forests has changed and the tree species composition is not original [54,55]. Accurate assessment of the relative 'naturalness' presents a challenge in such conditions. Relatively natural communities were represented by a selection of climax tree species on one plot [4]: the sessile oak (Quercus petraea (Matt.) Liebl.), European beech (Fagus sylvatica L.), European silver fir (Abies alba Mill.), Norway spruce (Picea abies (L.) H. Karst.), and mountain pine (Pinus mugo Turra). We filtered out the fourth through sixth degree of naturalness with 'semi natural' forests [56] to be as close as possible to the assumption of PNV in the concept of FVZs. We thus excluded plots with major introduced species, second growth plantations (spruce/pine monocultures), and seral and ecotone vegetation.

The CFEC system is based on "the vegetation potential" following the concept of PNV and relative stability of site properties (the physical environment). Considering the PNV concept, potential vegetation classifications should be relatively stable through a time so that a class label is applicable for a long time exceeding a rotation period. Considering relatively fast stand development, there are existing vegetation options (existing/actual stand development types) within the Management Complexes for forest management purposes. Those options should be sufficient for up to one rotation period (ca. 100 years).

We designated sampling plots for 41 Natural Forest Areas, 9 Forest Vegetation Zones and two major phytogeographic areas, Hercynicum and Carpaticum $(\mathrm{H} / \mathrm{C})$. Natural Forest Areas, FVZs and $\mathrm{H} / \mathrm{C}$ were hereafter considered analytical classes.

\subsection{Data Analysis}

(1) We ran Random Forests (RF) [57] of the physical environment represented by external explanatory factors (Table 1) to: (1) discriminate among classes (H/C, NFA, and FVZ); and (2) identify those factors significantly associated with these classes. We used the full data set $(11,885$ plots) to check discrimination between $\mathrm{H} / \mathrm{C}$ [46], and then subsets of $\mathrm{H} / \mathrm{C}$ to discriminate among NFAs and FVZs within $\mathrm{H} / \mathrm{C}$ and thus confronted H/C by NFAs and FVZs. We dropped NFA 2, 32 and 37 from the analysis due to under sampling (NFA 2/19 plots, 32/27, 37/12). Similarly, we dropped the 9th FVZ (41 plots) from the Hercynicum, and 7th and 8 th $\operatorname{FVZ}(21,1)$ from the Carpaticum subset. This approach appeared to be more realistic than 'artificially' balancing the data by down or up weighting.

Results were produced for all classes including among-class partial misclassification errors (taken from the RF confusion matrix). Important factors (the most influential when assigning classes to observations in the RF algorithm) were ranked in the RF variable importance analysis (parameter importance) according to Mean Decrease Accuracy and Mean Decrease Gini. For the machine-learning training (to grow a 'forest'), we used ntree $=500$ and 1000 (a number of trees as a function in R) and $m t r y=1,2,4,6,8,10,20$ (a number of variables randomly used at each split) [58].

(2) We used the principal components analysis (PCA) as a free ordination [59] to interpret principal components (PCs) (gradients in environmental space) associated with important environmental factors defined by the RF classification for both Hercynicum and Carpaticum. Correlation types of a cross-products matrix (data were centralized and standardized) and an orthogonal rotation option were used to get independent, mutually uncorrelated PCs [60]. We transformed the factors with $\mid$ skewness $\mid>1$ to be close to multivariate normality and reduce necessary intercorrelations. We checked the dataset for outliers [61]. Significance of PCs were tested using a Monte Carlo randomization test with 1000 runs. We calculated the linear (parametric Pearson's $r$ ) and rank (nonparametric Kendall's tau) correlation coefficients (loadings) as relationships between the ordination scores (axes) and the environmental factors. We set the threshold for $r$ and tau $>0.4$ (e.g., [62]).

(3) While the physical environment is at the core of the concept of NFAs, vegetation is a basis for discrimination of FVZs. Therefore, we analyzed floristic elements to gauge their performance as indirect classifiers of macro- and mesoclimatic conditions.

(a) We used the unconstrained-free nonmetric multidimensional scaling (NMS) of species data: (1) to look for patterns in a complex species-rich space, and (2) to account for expectation of non-linear 
relationships among species [59]. Prior to the NMS ordination, we deleted rare species with an occurrence of less than $1 \%$ in the sample plots. We logged transformed species abundances (a cover percentage was used as the original unit). We checked the data sets' properties (e.g., common vs. rare species numbers), and then standardized species by the binary relativization with respect to median, mean and generally in order to equalize common and rare species, and emphasize optimal parts of a species range $[59,63]$. The relationship between common and rare species was checked by dominance curves [59]. We used Sørensen distance and a Monte Carlo randomization test with 250 permutations to test the significance of the NMS ordination [61]. We considered an orthogonal relationship among axes, created a visual simulation of sample plots with their designation to FVZs by constructing convex hulls (envelopes) and calculating potential plot outliers (SD $>2$ ). We then calculated expression between the relationship of the species patterns (represented by significant NMS scores) with the physical environment (significant PC scores) by $r$ and tau loadings. NMS axes are not directly interpretable [59] therefore, the association of vegetation with the environmental ordination was necessary.

Relative positioning of FVZs in the species space was tested using the adonis function to perform multivariate analysis with a Bray-Curtis distance matrix using the vegan package $[64,65]$. Plot dispersion patterns within each FVZ were compared using the betadisper function in vegan using the same Bray-Curtis dissimilarity index. This function calculates multivariate homogeneity of plot dispersion between plots based on species abundance and is a multivariate analogue of the Levene's test for homogeneity of variances [65]. To test differences for dispersions in FVZs, analysis of variance was performed to measure the distance between plots and the FVZ centroid.

(b) We ran RF of species data (the same as used in NMS) to: (1) discriminate among FVZ classes; and (2) identify those species significantly associated with these classes. For the machine-learning training, we used ntree $=500$ and 1000 and $m$ try $=10$ through 40 .

The randomForest package [58]) of $\mathrm{R}$ (version 3.0.0 [64]) was used for the RF analysis and PC-ORD 6 [61] for NMS ordination. ArcGIS 10.3 (ESRI, Redlands, LA, USA) software with the Spatial Analyst superstructure and SAGA GIS software (Institute of Geography, University of Hamburg, Hamburg, Germany) were used for the calculation of the geomorphic indices.

\section{Results}

(1) RF does not constitute any error threshold value. It depends on research objectives and nature of the analysis, where an expected threshold is supposed to be designated. For complex datasets like ours, we designated the error threshold at a level of $20 \%$.

Classification of the entire environmental dataset (11,885 plots, 58 factors) within the supervised framework of the $\mathrm{H} / \mathrm{C}$ class revealed a general misclassification error of $0.2 \%$ (mtry $=4-8$, ntree $=500$ or 1000). $\mathrm{H} / \mathrm{C}$ classes revealed a partial within-class error of $0.06 \%$ and $0.63 \%$ respectively. As this result was consistent with a previous investigation by Kusbach [46], the strong division to the H/C subsets were used in the next assessment of NFAs and FVZs.

Classification of the Hercynicum environmental subset (9349 plots, 58 factors) within the supervised framework of the NFA class revealed a general misclassification error of $4 \%$ (mtry $=8$, ntree $=500$ or 1000). The RF confusion matrix showed the majority of NFAs as very well classified $(<10 \%$ of the partial error). NFA $6,15,26$, and 31 revealed satisfactory partial errors of $12,10,19$, and $15 \%$ respectively. The combined RF variable importance (based on both Mean Decrease Accuracy and Mean Decrease Gini) ranked all factors and pointed to climatic factors, especially precipitation, as the most differential among NFAs (Table 2). Climatic factors were better predictors of NFAs than geomorphic indices and soil types for Hercynicum.

Classification of the Carpaticum environmental subset (2524 plots, 58 factors) within the supervised framework of the NFA class revealed a general misclassification error of $2 \%$ $(m t r y=8, n t r e e=500$ or 1000). The RF confusion matrix showed a partial error $0.6,0.5,1.2,4.4,3.1$, $5.5 \%$ for NFAs $35-41$ (except the dropped NFA 37 ) respectively. The combined RF variable importance 
ranked all factors, the most differential among NFA see in Table 2. Climatic factors and soil properties were better predictors of NFAs than geomorphic indices for Carpaticum.

Table 2. The best Random Forests (RF) predictors of NFA based on both Mean Decrease Gini (MDG) and Mean Decrease Accuracy (MDA) for Hercynicum and Carpaticum.

\begin{tabular}{lccc}
\hline & & \multicolumn{2}{c}{ NFA } \\
\hline & & MDG & MDA \\
\hline \multirow{5}{*}{ Hercynicum } & mean precipitation & - & 67 \\
& 05 mean precipitation & 430 & - \\
& 06 mean precipitation & 549 & 81 \\
& 07 mean precipitation & 476 & - \\
& 10 mean precipitation & 462 & 73 \\
& 12 mean precipitation & 380 & - \\
& 01 mean temperature & - & 65 \\
& Valley depth & - & 72 \\
\hline \multirow{5}{*}{ Carpaticum } & 05 mean precipitation & 209 & 39 \\
& 05 mean precipitation & 130 & - \\
& 06 mean precipitation & 212 & 40 \\
& 08 mean precipitation & 233 & 48 \\
& 09 mean precipitation & 111 & - \\
& Texture & - & 35 \\
& Soil substrate & - & 34 \\
\hline
\end{tabular}

Classification of the Hercynicum environmental subset (9308 plots, 58 factors) within the supervised framework of the FVZ class revealed a general misclassification error of $23 \%$ ( $m$ try $=16$, ntree $=500$ or 1000). The RF confusion matrix showed a partial error 32, 31, 23, 32, 15, 22, 14 and 20\% for FVZ 1-8 respectively. Neighbors of a given FVZ (along the diagonal of the confusion matrix) comprised a majority of misclassified plots. Thus, these adjacent FVZs overlapped. The Mean Decrease Accuracy variable importance pointed to macroclimatic factors (precipitation and temperatures for Mean Decrease Gini) and soils as the most differential among FVZs (Table 3). Climatic factors and soils were better predictors of FVZs than geomorphic indices for Hercynicum.

Table 3. The best RF predictors of FVZ based on both MDG and MDA for Hercynicum and Carpaticum.

\begin{tabular}{lccc}
\hline & & \multicolumn{2}{c}{ FVZ } \\
\hline & MDG & MDA \\
\hline 01 mean precipitation & - & 61 \\
03 mean precipitation & - & 63 \\
Hercynicum & - & 78 \\
& 06 mean precipitation & 285 & - \\
& 05 mean temperature & 288 & - \\
& 11 mean temperature & 396 & - \\
& Annual mean temperature & 336 & - \\
& Soil subtype & 291 & 75 \\
& Soil type & - & 66 \\
\hline \multirow{5}{*}{ Carpaticum } & 05 mean precipitation & 159 & 43 \\
& 06 mean precipitation & 125 & 42 \\
& 08 mean precipitation & - & 33 \\
& 12 mean precipitation & 113 & 38 \\
& 03 mean temperature & 99 & - \\
& 05 mean temperature & 91 & - \\
& Terrain roughness index & - & 33 \\
\hline
\end{tabular}


Classification of the Carpaticum environmental subset (2514 plots, 58 factors) within the supervised framework of the FVZ class revealed a general misclassification error of $16 \%$ ( $m$ try $=16$, ntree $=500$ or 1000). While the RF confusion matrix showed FVZs 1,3 and 5 as very good, (a partial error 7.6, 11.8, and 8.2\%), FVZs 2, 4, 6 revealed partial errors of 38.126 .5 and $24.2 \%$ respectively. Again, neighbors of a given FVZ comprised a majority of misclassified plots and these adjacent FVZs overlapped. The most differential factors among FVZ of the Carpaticum see in Table 3. Climatic factors were better predictors of FVZs than geomorphic indices and soil properties for Carpaticum.

(2) The PCA ordination of the Hercynicum subset (4500 plots, 20 important factors from the RF classification) resulted in three significant PCs $(p=0.001)$, explaining respectively 46,15 and $11 \%$ of the total variance within the climatic and geomorphic indices (Figure 2). The most important principal component (PC1) was associated with macroclimatic factors (temperature, precipitation). PC1 was interpreted as a macroclimate gradient. PC2 was highly associated with SAGA $(r=-0.8$, tau $=-0.6)$, TRI $(0.8,0.6)$, Topex $(-0.6,-0.4)$ and TCIlow $(-0.5,-0.4)$. We interpreted this as a topographically based soil moisture gradient. PC3 was highly associated with VD $(-0.9,-0.7), \mathrm{HNO}$ $(0.7,0.5)$ and Topex $(0.6,0.4)$, which we interpreted as a valley thermic inversion gradient (Figure 2 , Supplementary Material B).

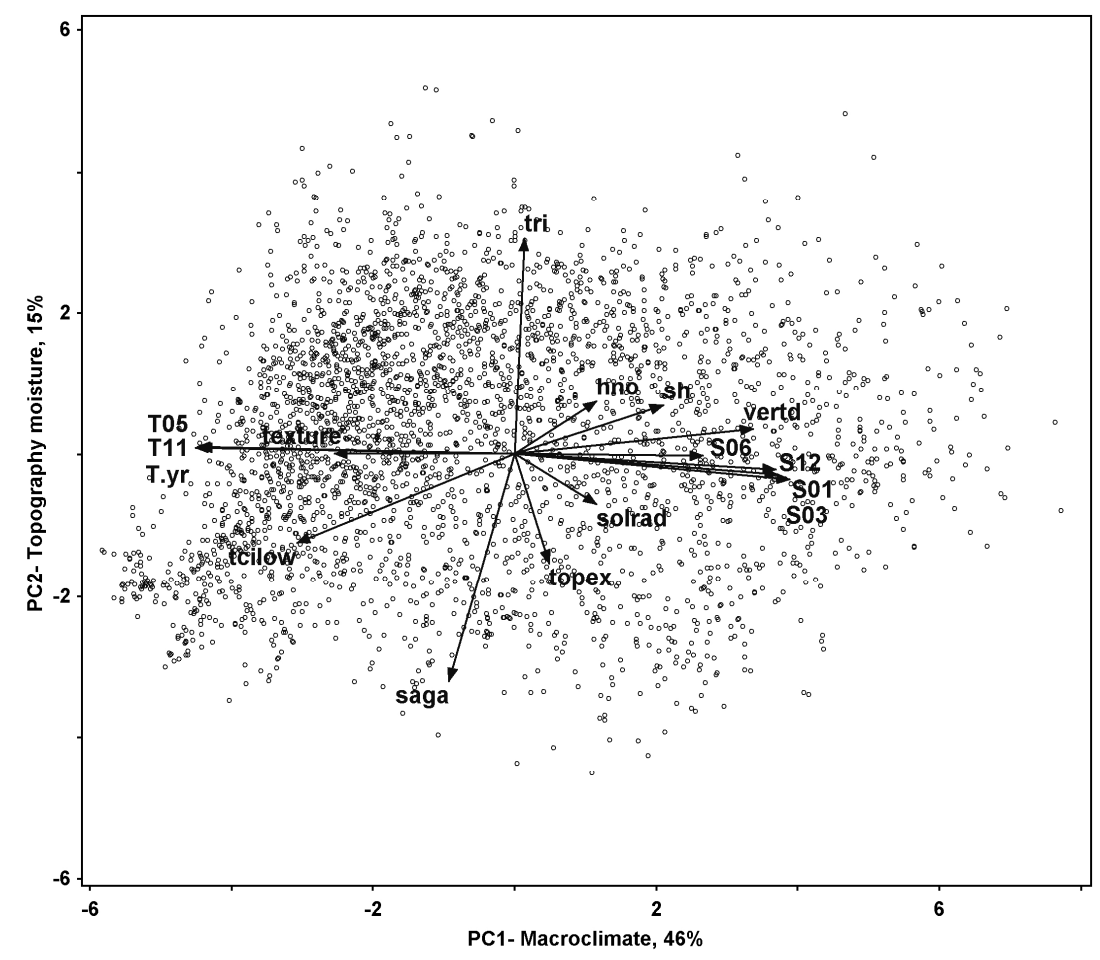

Figure 2. A biplot of sample plots and influential environment factors with significant gradients in the principal components analysis (PCA) ordination for the Hercynicum phytogeographic region. See Table 1 for the factors' abbreviations.

The PCA ordination of the Carpaticum subset ( 2535 plots, 21 important factors from the RF classification) resulted in three significant PCs $(p=0.001)$, explaining respectively 44,16 and $11 \%$ of the total variance within the climatic and geomorphic indices (Figure 3). The most important principal component (PC1) was associated with macroclimatic factors (temperature, precipitation). PC1 was interpreted as a macroclimate gradient. PC2 was highly associated with VD $(r=0.8$, tau $=0.7)$, HNO $(-0.8,-0.6)$, Topex $(-0.8,-0.6)$ and PO $(-0.7,-0.5)$. We interpreted this as a valley thermic inversion gradient. PC3 was highly associated with Diur $(0.9,0.8)$, Solrad $(0.9,0.7)$ and av $(-0.8,-0.6)$, which we interpreted as an exposure-to-sun gradient (Figure 3, Supplementary Material C). 


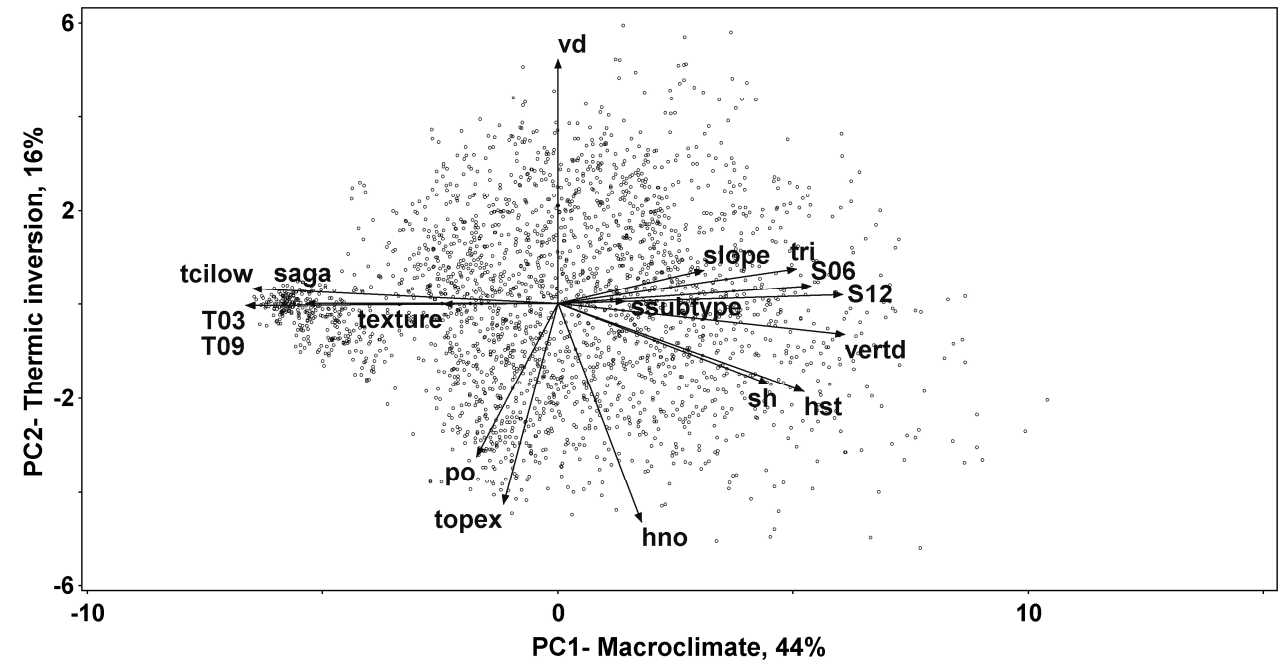

Figure 3. A biplot of sample plots and influential environment factors with significant gradients in the PCA ordination for the Carpaticum phytogeographic region. See Table 1 for the factors' abbreviations.

(3a) In NMS, the binary relativization with respect to median showed the best results compared to the other relativizations. Dominance curves for the H/C subsets were lined up, i.e., a difference between common and rare species was balanced. The ordination produced a meaningful distribution of vegetation plots in the ordination space for this type of relativization.

For the Hercynicum subset (3222 plots, 317 species), the final solution after 78 iterations with final stress at $18.5(p=0.004)$ and instability at 0.0 suggested two dimensions (vegetation gradients) representing $65 \%$ of the after-the-fact amount of variation within the subset (the first axis 45 , second 20\%). For the Carpaticum subset (2535 plots, 340 species), the final solution after 111 iterations with final stress at $19.7(p=0.004)$ and instability at 0.0 suggested two dimensions representing $69 \%$ of the total amount of variation within the subset (38\% of the first axis, $31 \%$ of the second).

We found a significant relationship between vegetation and the environment represented by macroclimate (PC1 gradient). PC1 was highly associated with NMS1 for both Hercynicum and Carpaticum $(r=-0.7$, tau $=-0.5)$ (Supplementary Material D, E). In Hercynicum, the species significantly associated with NMS1 and macroclimate were Picea abies $(r=0.5$, tau $=0.4)$, Vaccinium myrtillus $(0.8,0.6)$, Vaccinium vitis-idaea $(0.6,0.5)$, Vaccinium uliginosum $(0.5,0.4)$, Calamagrostis villosa $(0.5,0.5)$, Avenella flexuosa $(0.5,0.4)$ for a colder and wetter part of the gradient. For a warmer and drier part of the gradient, they were Poa nemoralis $(-0.6,-0.5)$, Galium odoratum $(-0.5,-0.4)$, Viola reichenbachiana $(-0.5,-0.4)$, Melica nutans and Mercurialis perennis $(-0.4,-0.4)$. In Carpaticum, the species significantly associated with macroclimate were Fagus sylvatica $(0.5,0.5)$, Brachypodium sylvaticum $(0.5,0.4)$, Luzula luzuloides $(0.5,0.4)$, Vaccinium myrtillus $(0.4,0.4)$ for a colder and wetter part of the gradient. For a warmer and drier part of the gradient, it was Geum urbanum $(-0.5,-0.4)$. We found no association between the species, designated FVZs and the other environmental gradients interpreted by PCA (Supplementary Material D, E).

Convex hulls were computed to outline FVZs in the species study areas. FVZs were ordered following the macroclimatic gradient suggested by PCA and RF within NMS biplots (Figures 4 and 5). The plant species composition and its homogeneity among FVZs significantly differed for Hercynicum (adonis: $\mathrm{R}^{2}=0.240, p<0.01$; betadisper: $\mathrm{F}=340.43, p<0.01$ ) and for Carpaticum (adonis: $\mathrm{R}^{2}=0.221$, $p<0.01$; betadisper: $\mathrm{F}=124.59, p<0.001$ ). For both, the mountain $\mathrm{FVZs}$ were more homogenous (average distance to group centroid $<0.5$ ) than the low-elevational FVZs (average distance to centroid $>0.5$ ). A permutation test for adonis results revealed small differences among FVZs (Supplementary Material F). These findings were consistent with misclassification between the FVZ neighbors and overlapping of FVZs. For the worst FVZ in the Hercynicum adonis test, we indicated the plot outliers as azonal sites 
reflecting mesoclimate rather than macroclimate. Cutting off these outliers improved homogeneity and robustness of the FVZ (Supplementary Material G).

(3b) Classification of the Hercynicum vegetation subset (3222 plots, 317 species) supervised by the FVZ revealed a general misclassification error of $35 \%($ mtry $=20$, ntree $=1000)$. The RF confusion matrix showed a partial error 20,32, 43, 52, 36, 35, 34 and 28\% for FVZ 1-8 respectively. The combined RF variable importance ranked all species. Mean Decrease Accuracy values for important and overlapping species with NMS were: Fagus $2=48$, Calamagrosris villosa $=40$, Picea $3=38$, Fagus3 $=37$, Vaccinium myrtillus $=33$, Abies2 $=33$, Avenella flexuosa $=25$, Quercus petraea $9=28$, Galium odoratum $=25$, Poa nemoralis $=23$; Mercurialis perennis $=23$. Mean Decrease Gini values were: Calamagrosris villosa $=82$, Fagus $2=76$, Picea $3=63$, Fagus $3=54$, Vaccinium myrtillus $=43$, Avenella flexuosa $=34$, Poa nemoralis $=33$, Quercus petraea $9=33$, Abies $2=31$, Galium odoratum $=29$, Mercurialis perennis $=22$. Climax tree species appeared to be good predictors of FVZs for Hercynicum.

Classification of the Carpaticum vegetation subset (2514 plots, 340 species) supervised by the FVZ revealed a general misclassification error of $22 \%(m t r y=40, n$ tree $=500)$. While the RF confusion matrix showed FVZs 1, 3 and 5 as very good, (a partial error 10, 14, and 7\%), FVZs 2, 4, 6 revealed partial errors of 32,52 and $86 \%$ respectively. Neighbors of a given FVZ comprised a majority of misclassified plots and these adjacent FVZs overlapped. The combined RF variable importance ranked all species. Mean Decrease Accuracy values for important and overlapping species with NMS were: Carex pilos $a=38$, Fagus2 $=34$, Abies $2=25$, Quercus petraea $3=25$, Quercus petraea $4=25$, Vaccinium myrtillus $=17$, Picea $3=14$, Luzula luzuloides $=14$, Mean Decrease Gini values were: Carex pilosa $=87$, Fagus2 $=77$, Abies2 $=63$, Quercus petraea3 $=62$, Quercus petraea $4=49$, Picea $3=22$, Luzula luzuloides $=14$, Vaccinium myrtillus $=13$. Climax tree species appeared to be good predictors of FVZs for Carpaticum. Major important species (including the understory) revealed by NMS and RF overlapped.

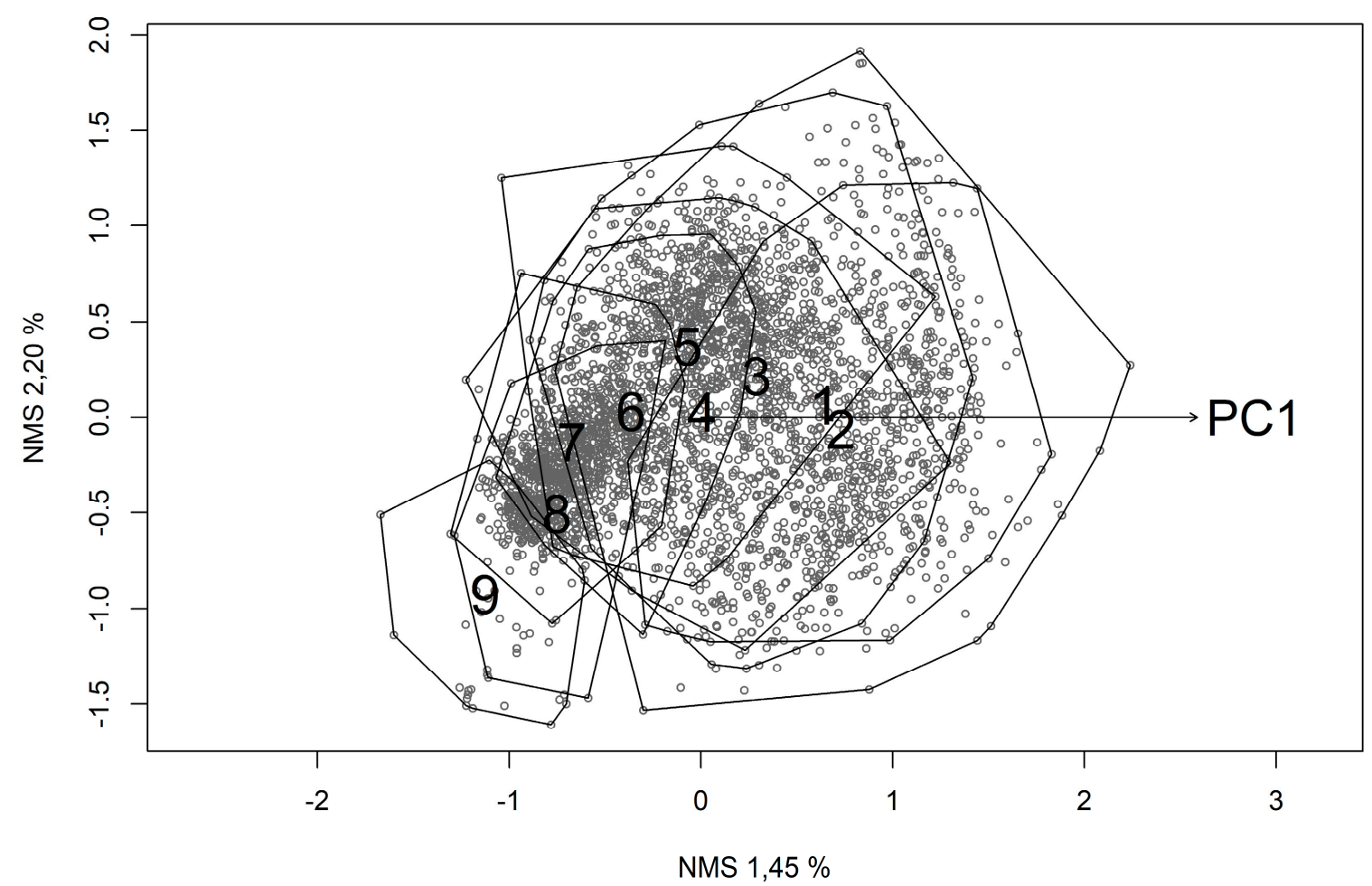

Figure 4. A biplot of sample plots and influential gradients in the nonmetric multidimensional scaling (NMS) ordination for the Hercynicum phytogeographic region. Arabic digits display a relative position of Forest Vegetation Zone centroids, while convex hulls visualize their span. The first principal component (PC1) is the microclimatic gradient from the PCA ordination. 


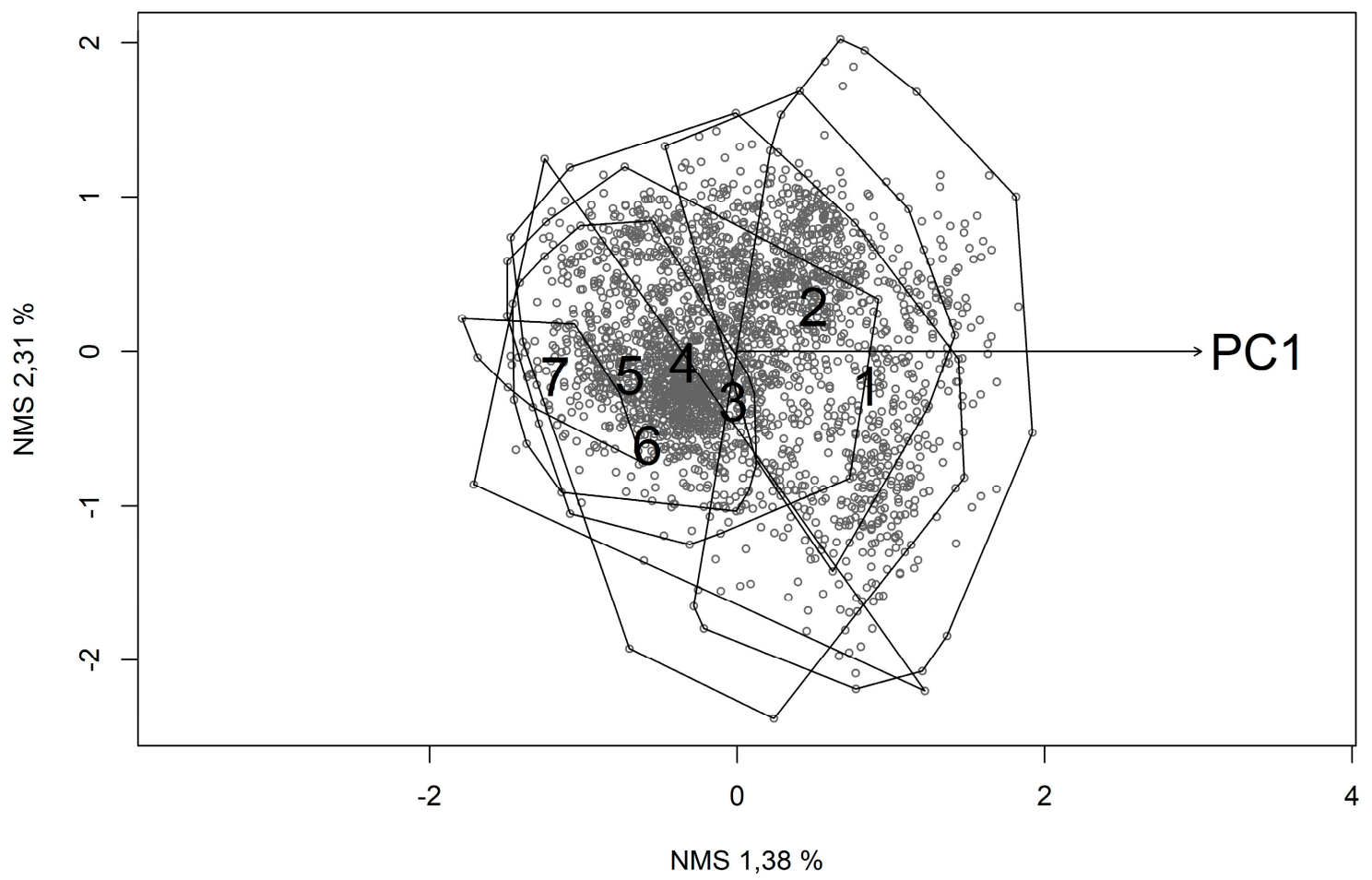

Figure 5. A biplot of sample plots and influential gradients in the NMS ordination for the Carpaticum phytogeographic region Arabic digits display a relative position of Forest Vegetation Zone centroids, while convex hulls visualize their span. PC1 is the microclimatic gradient from the PCA ordination.

\section{Discussion}

\subsection{Natural Forest Areas}

The categorization of Natural Forest Areas generally performed very well in the analysis because of a low misclassification error. However, some areas such as 6, 15, 26, and 31, along with under sampled NFA 2, 32, and 37, appeared incorrect in the analysis but which may serve as examples for further investigations. These areas were either too small or represented lowland to mountain transitions. Expert knowledge attempts were made to move NFA borders closer to ecological reality and retain clear but not ecological borders (artificial channels, roads, railroads). Future actions might utilize RF classifiers, for example, to help to justify fuzzy areas' borders. RF is useful for identifying problematic plots along these borders based on probabilities being misclassified by using a 'predict' command.

Additionally, the conventional division into Hercynicum and Carpaticum should be considered within the system because: (1) it is consistent with continental-scale climatic-vegetation classifications $[12,66,67]$; and (2), it is ecological, and performed well indicated bythe analysis.

\subsection{Forest Vegetation Zones}

The classifications of FVZs performed worse than NFAs, despite the fact that they comprised necessary attributes demanded by the FVZ concept [40] i.e., vegetation, macro/mesoclimate and a FVZ field designation. The RF produced analogous results to both ordinations and tests for FVZ significance and homogeneity. Macroclimate was the best predictor of FVZs within the H/C subsets (Figures 4 and 5).

Low-elevational FVZs, however, performed worse than montane zones in both Hercynicum and Carpaticum. Classification results supported by azonal detection of the NMS outliers pointed to a lack of spatial vegetation-environmental relationships, putting into question the vegetation-driven FVZ 
concept. Two reasons or manifestations may explain a shortage of these relationships (Supplementary Material D, E):

(1) A human-caused disturbance noise. Existing (actual) vegetation is far from PNV in central Europe (e.g., [54]).

We analyzed changes in vegetation composition of forested areas mainly in the Hercynicum area with the naturalness degree 4 [56], as the frequently occurring species such as Picea abies, Pinus sylvestris and Larix decidua are not natural co-dominant species accompanying Quercus petraea and Fagus sylvatica in lower FVZs (1-3), and Picea abies does not naturally accompany Fagus in higher FVZs (4-5). It is probably the reason why Picea abies was the only significant tree species associated with macroclimate accompanied by Vaccinium myrtillus, Vaccinium vitis-idaea, Vaccinium uliginosum, Calamagrostis villosa and Avenella flexuosa at the same end of the macroclimatic gradient in NMS. Results for Pinus mugo may also have been limited by general undersampling of the zone and difficulties associated with precisely delineating FVZ 8 from FVZ 9 due to past pasture management practices and shifting of the upper tree line [68-70]. Abies alba occurrence in Hercynicum and Carpaticum has been strongly affected by extensive human impact beginning as early as the Medieval period [71], and subsequently suffered further decline in Modern times in response to conditions such as periods of marked air pollution, i.e., the 1970s and 1980s [72].

In Carpaticum, Fagus sylvatica was revealed as a tree species associated with macroclimate accompanied by Brachypodium sylvaticum, Luzula luzuloides and Vaccinium myrtillus. Other important tree species in classification were Quercus petraea and Abies alba. We suggest that changes in the proportionate occurrence of Fagus and Quercus in NMS were mainly due to past practices of intensive coppice management (e.g., [73,74]).

Better results of vegetation classification for Carpaticum confirmed its more natural floristic composition and a heavier human-caused disturbance vegetation noise especially in a lower-'agricultural' Hercynicum landscape. Vegetation classification demonstrated a leading role of climax tree species (edificators) Quercus petraea, Fagus sylvatica, Abies alba and Picea abies in vegetation zonation [40].

(2) Only two significant species dimensions (NMS1-2) represented broad vegetation information. Forty five percent (NMS1) and 38\% (NMS 2) of information respective to H/C (Figures 4 and 5) was in fact a response to the one of the three significant environmental gradients (Figures 2 and 3). The remaining vegetation information represented as a noise proved puzzling and consequently, we were unable to correlate it with the environmental data. Macroclimate showed to be the best predictor of FVZs for both $\mathrm{H} / \mathrm{C}$ in all the analyses. Mesoclimate does not matter in the FVZ landscape-level settings.

The FVZ concept implicitly combines an altitudinal change of macroclimatic factors with mesoclimate detected as independent on macroclimate in our analysis (see also Figures 2 and 3) via explicit designation of FVZs by focal tree generalists. This combination effectively led to the delineation of zonal (driven by macroclimate) and azonal (driven by mesoclimate) FVZs (Figure 1b,c).

Environmental and vegetation results were in agreement with both classification (RF) and NMS ordination. Moreover, classification of the environment provided better results than classification of vegetation for both Hercynicum and Carpaticum. Taking into account significance of the environment in our analysis, we propose that it would be ill-advised to base delineation of forest vegetation zones via explicit a priori designation by climax tree species without taking significant environmental limits such as independence of the environmental gradients into consideration. This is especially true for more compositionally changed forests of Hercynicum. We recommend instead using a novel interpretation of landscape-level vegetation zonation, keeping vegetation responses 'simple' by responding to only the most significant environmental gradient, i.e., macroclimate, because again, mesoclimate is not significant at the landscape-level settings in our FVZ analysis. This approach assumes proper stratification of both vegetation and environmental data, for example, by use of the zonal concept [11]. Local climatic, topographical and edaphic extremes (warm south-facing slopes, cool north-facing slopes, cold depressions), are excluded and only intermediate environmental conditions 
are considered in stratification of late-seral vegetation ([75] sensu [11]). The concept can solve the azonality issue and explicitly include the 'zonal' environment into the consideration. Azonality should be excluded from the FVZ concept because this delineation lowers accuracy of existing zonation. A zonal stratification is advantageous for using environmental limits [11], including soil factors applied directly on a site [75]. Use of these limits together with late-seral vegetation strengthens the PNV approach. This concept has worked properly in BEC in BC that way for decades. It was also applied in the Modoc National Forest in northern California [76] and in the central Rocky Mountains [75].

Additionally, relatively new methods in quarter paleoecology such as pedoanthracology (e.g., $[77,78]$ ) combined with routine dendrochronological techniques $[79,80]$ may be helpful when reconstructing a landscape and its vegetation 'story' to a desirable time period including a historic gradient to the relatively static physical environment. In our opinion, the addition of paleo studies (e.g., [71,81-84]) will be necessary for a defensible PNV, certainly in the context of forest assessment for central Europe [85].

\subsection{Potential of Improved Vegetation-Driven Classifications}

We suggest that limited accuracy of FVZs discredits their applied power. Earlier efforts to delineate such units were driven by field experience, or by as little as an educated guess, as rigorous analytical tools did not yet exist. These efforts relied on subjective constructions and over utilization of rather vague expert knowledge [34].

There is an enormous value in ecological classifications when applied to forest ecology, land management, nature conservation (e.g., [31,33,86-88]) and other important fields such as climate change and disturbance predictions [89,90]. Additionally, considering ecological classifications in a context of multidisciplinary efforts (e.g., contributing to ongoing work in anthracology, dendrochronology and climatology) may be very useful to further develop ecological classifications worldwide. In BC, for example, a recent topic of ongoing discussion relates to how the application BEC tools to cumulative vegetation-environmental assessments might benefit industries not directly related to forestry, such as the energy sector [91]. Multidisciplinary efforts could also be extremely useful in habitat typing, a typical vegetation-driven land classification system that has been used in forest ecosystem management in extensive areas of USA for more than 50 years. There exists a real need for formal quantification based on enhanced information (e.g., derived from progressive technologies such as remote sensing, or through using new climatic models).

\subsection{Perspectives of Ecological Classifications}

Our study revealed issues that contradict expert knowledge based concepts respected for decades with respect to approaches via formal quantification of available data, which is consistent with a recent call for advanced classifications in Europe [46,92,93], and in North America [86,87,94-96]. Findings of this study may point to similar problems accompanying other classifications where landscape units may not be as strong as expected.

Recently, considerable effort has been invested into formulating stable continental forest unit descriptors [97-99] with the view of providing regional structures such as CFEC with a reliable, top-down framework. These structures should be equipped with quality data to support sustainable management as much as possible, in compliance with Pan European legislation [100-102]. In regions lacking established ecological classifications such as West Africa [103], Mongolia [104], northwest Himalayas [105], Greenland [106], and Chile [107], this approach holds considerable potential for developing ecologically sound structures aimed at improving local management.

Current advancements in disturbance ecology have rendered conventional ecological frameworks obsolete. These frameworks have been criticized as being 'static', and unable to sufficiently reflect ecosystem dynamics. Disturbances shape vegetation patterns faster than relatively stable site factors. Nevertheless, we are convinced that a role of classic site components, including soils and combined with new techniques, in the assessment of vegetation patterns holds considerable potential in 
a changing world. Forest classifications have been always considered an important part of the ecological basis for developing sustainable management guidelines $[107,108]$. We propose that our central European study be considered a general methodology and used as an example for verifying landscape-level vegetation classifications where traditional concept settings might be otherwise problematic. Ecological classifications matter in the 21st century!

\section{Conclusions}

The landscape-level units of the Czech Forest Ecosystem Classification generally succeeded in differentiating environmental conditions. In homogeneous environments of $\mathrm{H} / \mathrm{C}$, the NFA proved highly successful, while the FVZ did not succeed as well in classification and ordination of available vegetation and environmental data. Classification of the environment provided better results than classification of vegetation for both Hercynicum and Carpaticum. Using the PNV concept, we suggest not relying only on vegetation and its floristic elements in classification analyses, but including also the significant environment for direct classification of FVZ and similar vegetation-based units mainly in altered compositional settings such as the central European forests. We suggest a novel interpretation of FVZ via a proper stratification of vegetation throughout the environment by employing the zonal concept. Furthering our understanding of coarse-scaled vegetation-environmental relationships is fundamental, not only in the context of forest ecology and management, but towards improving lower, fine-scaled classification levels. Given its broad practical and theoretical acceptance, high-applied value, importance for a local legislation and recent Pan European processes, we recommend re-examination of the concept of FVZ using a new data sources such as (i) the National Forest Inventory with a random plot sampling design; (ii) pedoathracology as a promising historic gradient data source; and (iii) potential mesoclimatic modeling.Valuable expert knowledge and empiricism should be combined with up-to-date, formal quantification in the assessment of accepted but obsolete land classification structures. This study raised similar conceptual issues for other ecological classifications worldwide. It is consistent with recent calls for advanced multidisciplinary ecological classifications in Europe and North America.

Supplementary Materials: The following are available online at www.mdpi.com/1999-4907/8/12/461/s1: A. Description of geomorphic indices based on Digital Terrain Model created on Digital Relief Model of 4th Generation; B. PCA for the Hercynicum phytogeographic region. Parametric Pearson's r and nonparametric Kendall's tau correlation coefficients (loadings) for significant ordination axes; C. PCA for the Carpaticum phytogeographic region. Parametric Pearson's r and nonparametric Kendall's tau correlation coefficients (loadings) for significant ordination axes; D. A relationship between the PCA and NMS ordinations represented by Pearson's $r$ and Kendall's tau correlation coefficients (loadings) for the Hercynicum phytogeographic region; E. A relationship between the PCA and NMS ordinations represented by Pearson's $r$ and Kendall's tau correlation coefficients (loadings) for the Carpaticum phytogeographic region; F. A permutation test of the adonis analysis; G. Outliers for the worst FVZ 1 in the Hercynicum phytogeographic region. The outliers (black circles) were identified as azonal sites reflexing mesoclimate rather than macroclimate. Cutting off the outliers improved homogeneity and robustness of the FVZ (average distance to the group centroid dropped).

Acknowledgments: We thank the Czech Forest Management Institute for the data provided for the purpose of this study. We also thank Dean Meason and Aimee Orsini for the English revision and anonymous reviewers for providing invaluable comments and suggestions on drafts of this paper. This paper was supported by the project "Building and development of the multidisciplinary team on a platform of landscape ecology, CZ.1.07/2.3.00/20.0004" and "Internal Grant Agency of the Faculty of Forestry and Wood Technology Mendel University in Brno, LDF_PSV_2017006".

Author Contributions: A.K. initiated the study, carried out the statistical analysis and drafted the manuscript. J.Š. carried out and reviewed the statistical analysis and the manuscript. V.Z. prepared the database and revised the manuscript. M.F. cleaned and prepared vegetation data, revised and formatted the manuscript, T.M. carried out the G.I.S. analysis.

Conflicts of Interest: The authors declare no conflict of interest. 


\section{References}

1. Daubenmire, R. The roots of a concept (keynote). In Proceedings, Land Classifications Based on Vegetation: Applications for Resource Management, Moscow, ID, November 17-19, 1987; Ferguson, D.E., Morgan, P., Johnson, F.D., Eds.; U.S. Department of Agriculture Forest Service Intermountain Research Station: Ogden, UT, USA, 1989; pp. 3-6.

2. Kusbach, A.; Long, J.N.; Van Miegroet, H.; Shultz, L.M. Fidelity and diagnostic species concepts in vegetation classification in the Rocky Mountains, Northern Utah, USA. Botany 2012, 90, 678-693. [CrossRef]

3. Tüxen, R. Die Heutige Potentielle Natürliche Vegetation als Gegenstand der Vegetationskartierung; Angewandte Pflanzensoziologie 13; Bundesanstalt (Zentralstelle) für Vegetationskartierung: Stolzenau, Germany, 1956; p. 55.

4. Zlatník, A. Nástin lesnické typologie na biogeocenologickém základu a rozlišení československých lesi̊ podle skupin lesních typi̊ (An overview of forest classification based on biogeocoenological principals and discrimination of Czechoslovakian forests by forest type s. In Pěstění lesů III (Forest silviculture III); Polanský, B., Ed.; Státni Zemědělské Nakladatelství Praha: Praha, Czechoslovakia, 1956; pp. 317-400. (In Czech)

5. Küchler, A.W. The Potential Natural Vegetation of the Conterminous United States; Special Publication No. 36; American Geographical Society: New York, NY, USA, 1964; p. 116.

6. Schlenker, G. Entwicklung des in Südwestdeutschland angewandten Verfahrens der forstlichen Standortskunde. In Standort, Wald und Waldwirtschaft in Oberschwaben: Ergebnisse einer Gemeinschaftsarbeit in Einzeldarstellungen; Arbeitsgemeinschaft Oberschwäbische Fichtenreviere: Stuttgart, Germany, 1964; pp. 5-26.

7. Rowe, J.S. The common denominator of land classification in Canada: An ecological approach to mapping. In Proceedings of the Ecological Classification of Forest Land in Canada and Northwestern U.S.A., Vancouver, BC, Canada, 30 September-2 October 1977; U.S.A. Forest Ecology Working Group, Canadian Instite Forestry and Centre for Continuing Education, UBC: Vancouver, BC, Canada, 1978; pp. 195-198.

8. Damman, A.W.H. The role of vegetation analysis in land classification. For. Chron. 1979, 55, 175-182. [CrossRef]

9. Pfister, R.D.; Arno, S.F. Classifying forest habitat types based on potential climax vegetation. For. Sci. 1980, 26, 52-70.

10. Barnes, B.V.; Pregitzer, K.S.; Spies, T.A.; Spooner, V.H. Ecological forest site classification. J. For. 1982, 80, 493-498.

11. Pojar, J.; Klinka, K.; Meidinger, D.V. Biogeoclimatic ecosystem classification in British Columbia. For. Ecol. Manag. 1987, 22, 119-154. [CrossRef]

12. Bailey, R.G. Ecoregions: The Ecosystem Geography of the Oceans and Continents; Springer: New York, NY, USA, 1998; p. 176, ISBN 0-387-98311-2.

13. Cajander, A.K. The theory of forest types. Acta For. Fenn. 1926, 29, 1913-1929. [CrossRef]

14. Braun-Blanquet, J. Pflanzensoziologie: Grundzüge der Vegetationskunde, 1st ed.; Biologische Studienbücher. 7; Julius Springer: Berlin, Germany, 1928; p. 330.

15. Tansley, A.G. The use and abuse of vegetational concepts and terms. Ecology 1935, 16, 284-307. [CrossRef]

16. Sukachev, V.N.; Dylis, N.V. Fundamentals of Forest Biogeocoenology; Translated from the Russian Edition (Moscow, 1964) by J. M. Maclennan; Oliver and Boyd: Edinburgh, UK, 1968; p. 672.

17. Bissonette, J.A. Scale-sensitive ecological properties: Historical context, current meaning. In Wildlife and Landscape Ecology: Effects of Pattern and Scale; Bissonette, J.A., Ed.; Springer: New York, NY, USA, 1997; pp. 3-31, ISBN 978-1-4612-7338-7.

18. Cleland, D.T.; Avers, P.E.; McNab, H.W.; Jensen, M.E.; Bailey, R.G.; King, T.; Russell, W.E. National hierarchy framework of ecological units. In Ecosystem Management: Applications for Sustainable Forest and Wildlife Resources; Boyce, M.S., Haney, A., Eds.; Yale University Press: New Heaven, CT, USA, 1997; pp. 181-200.

19. Chen, J.; Brosofske, K.D.; Lafortezza, R. Ecology and Management of Forest Landscapes. In Patterns and Processes in Forest Landscapes; Lafortezza, R., Sanesi, G., Chen, J., Crow, T., Eds.; Springer: Dordrecht, The Netherlands, 2008; pp. 3-16, ISBN 978-1-4020-8503-1.

20. Zlatník, A. Přehled Slovenských lesů Podle Skupin Lesních Typů (An Overview of Slovak Forests by Forest Types Groups); Spisy Vědecké Laboratoře Biogeocenologie a Typologie lesa Lesnické Fakulty Vysoké Školy Zemědělské v Brně; Lesnická Fakulta Vysoké školy Zemědělské v Brně: Brno, Czechoslovakia, 1959; p. 195. (In Czech)

21. Plíva, K.; Žlábek, I. Přirodní Lesní Oblasti ČSR (Natural Forest Areas in the Czech Republic); Státní Zemědělské Nakladatelství Praha: Praha, Czechoslovakia, 1986; p. 313. (In Czech) 
22. Kilian, W.; Muller, F.; Starlinger, F. The Forest Growth Regions of Austria a Land Classification Based on Forest Ecology; FBVA Berichte: Wien, Austria, 1994.

23. Dahdouh-Guebas, F.; Triest, L.; Verneirt, M. The importance of a hierarchical ecosystem classification for the biological evaluation and selection of least valuable sites. Impact Assess. Proj. Apprais. 1998, 16, 185-194. [CrossRef]

24. Blasi, C.; Capotorti, G.; Frondoni, R. Defining and mapping typological models at the landscape scale. Plant Biosyst. Int. J. Deal. Asp. Plant Biol. 2005, 139, 155-163. [CrossRef]

25. Gauer, H.J.; Aldinger, E. Forest Ecologically-Based Nature Areas in Germany. Forest Growth Regions and Growth Districts with a 1:1,000,000 Map; Mitteilungen des Vereins für Forstliche Standortskunde und Forstpflanzenzüchtung: Freiburg, Germany, 2005.

26. McNab, H.W.; Cleland, D.T.; Freeouf, J.A.; Keys, J.E.J.; Nowacki, G.J.; Carpenter, C.A. Description of Ecological Subregions: Sections of the Conterminous United States; United States Department of Agriculture: Washington, DC, USA, 2007; Volume 76B, p. 80.

27. Townshend, E.; Pokharel, B.; Groot, A.; Pitt, D.; Dech, J.P. Modeling wood fibre length in black spruce (Picea mariana (Mill.) BSP) based on ecological land classification. Forests 2015, 6, 3369-3394. [CrossRef]

28. Pyatt, G.; Ray, D.; Fletcher, J. An Ecological Site Classification for Forestry in Great Britain; Bulletin 124; Forestry Commission: Edinburg, UK, 2001; p. 74, ISBN 0855384182.

29. Ray, D.; Xenakis, G.; Tene, A.; Black, K. Developing a site classification system to assess the impact of climate change on species selection in Ireland. Irish For. 2009, 66, 101-122.

30. Plíva, K. Typologický Systém ÚHúL (Forest Classification System of the Forest Management Institute); Ústav pro Hospodářskou Úpravu lesů Brandýs nad Labem: Brandýs nad Labem, Czechoslovakia, 1971; p. 90. (In Czech)

31. Haeussler, S. Rethinking biogeoclimatic ecosystem classification for a changing world. Environ. Rev. 2011, 19, 254-277. [CrossRef]

32. Kupfer, J.A.; Franklin, S.B. Evaluation of an ecological land type classification system, Natchez Trace State Forest, western Tennessee, USA. Landsc. Urban Plan. 2000, 49, 179-190. [CrossRef]

33. DeLong, C.S.; Griesbauer, H.; Mackenzie, W.; Foord, V. Corroboration of biogeoclimatic ecosystem classification climate zonation by spatially modelled climate data. BC J. Ecosyst. Manag. 2010, 10, 49-64.

34. Chytrý, M.; Schaminée, J.H.J.; Schwabe, A. Vegetation survey: A new focus for Applied Vegetation Science. Appl. Veg. Sci. 2011, 14, 435-439. [CrossRef]

35. Viewegh, J.; Kusbach, A.; Mikeska, M. Czech forest ecosystem classification. J. For. Sci. 2003, 49, 85-93.

36. Forest Management Institute Forest Typology. Available online: http://www.uhul.cz/nase-cinnost/lesnickatypologie (accessed on 22 August 2017).

37. Machar, I.; Vlčková, V.; Buček, A.; Vozenilek, V.; Šálek, L.; Jeřábková, L. Modelling of Climate Conditions in Forest Vegetation Zones as a Support Tool for Forest Management Strategy in European Beech Dominated Forests. Forests 2017, 8. [CrossRef]

38. Průša, E. Pěstování lesů na Typologických Základech (Cultivation of Forests Based on Forest Classification), 1st ed.; Lesnická Práce s.r.o.: Kostelec nad Černými Lesy, Czech Republic, 2001; p. 593, ISBN 80-86386-10-4. (In Czech)

39. Randuška, D.; Vorel, J.; Plíva, K. Fytocenológia a Lesnícka Typológia (Phytocoenology and Forest Typology), 1st ed.; Príroda: Bratislava, Czechoslovakia, 1986; p. 329. (In Czech)

40. Zlatník, A. Lesnická Fytocenologie (Forest Phytocoenology); Státni Zemědělské Nakladatelství Praha: Praha, Czechoslovakia, 1976; p. 495. (In Czech)

41. Kubošová, K.; Komprda, J.; Bednářová, Z.; Hájek, O.; Sáňka, M.; Jarkovský, J.; Matoušková, P.; Kalábová, T. Vyhodnocení dat Databáze Lesnické Typologie a Úpravy Typologického Systému ÚHÚL-1. Část (Data Evaluation of Forest Typology Database and Modifications of the Czech Forest Ecosystem Classification-Part 1); Research Centre for Toxic Compounds in the Environment: Brno, Czech Republic, 2010; p. 100. (In Czech)

42. Mikeska, M. Návrh tvorby a členění linií geograficky zonálních vegetačních stupňů (Proposal of formation and classification of outlines of geographically zonal vegetation tiers). In Problematika Lesnické Typologie II (The Question of Forest Typology II); Viewegh, J., Ed.; Česká Zemědělská Univerzita v Praze, Fakulta Lesnická, Katedra Dendrologie a Šlechtění Lesních Dřevin: Kostelec nad Černými Lesy, Czech Republic, 2000; Volume II, pp. 8-10. (In Czech)

43. Višňák, R. Aktuální stav typologického systému a možnosti jeho dalšího vývoje (A state and possibilities of development of the Czech Forest Ecosystem Classification). Lesn. Práce 2001, 80, 72-75. (In Czech) 
44. Šamonil, P. Paradigma lesnické typologie z pohledu dynamiky přirozených lesů (Paradigm of forest typology from a view of forestry practice). Lesn. Práce 2012, 91, 19-21. (In Czech)

45. Volařík, D. Application of digital elevation model for mapping vegetation tiers. J. For. Sci. 2010, 56, 112-120.

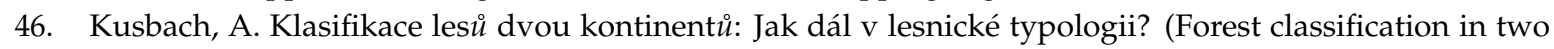
continents: What next with that?). Lesn. Práce 2012, 91, 30-33. (In Czech)

47. Zouhar, V. Stav lesnicko-typologického klasifikačního systému a možnosti jeho vývoje (The Czech Forest Ecosystem Classification-Present situation and development). In Geobiocenologie a její Aplikace v Lesnictví a Krajinářství. Sborník Př́spěvků z Konference Konané 6.-7. Prosince 2012 v Brně. (Geobiocoenology and Its Application in Forestry and Landscape Ecology, Proceedings of the Conference Held on 6-7 December 2012; Friedl, M., Ed.; Geobiocenologické Spisy; Lesnická Práce s.r.o.: Kostelec nad Černými Lesy, Czech Republic, 2013; Volume 15, pp. 218-224. (In Czech)

48. Zouhar, V. Database of Czech Forest Classification System. Biodivers. Ecol. 2012, 4, 346. [CrossRef]

49. Brázdil, K.; Bělka, L.; Dušánek, P.; Fiala, R.; Gamrát, J.; Kafka, O.; Peichl, J.; Šíma, J. Technická Zpráva k Digitálnímu Modelu Reliéfu 4. Generace DMR 4G; State Administration of Land Surveying and Cadastre: Prague, Czech Republic, 2012; p. 11. (In Czech)

50. Roberts, D.W.; Cooper, S.V. Concepts and techniques in vegetation mapping. In Proceedings, Land Classifications Based on Vegetation: Applications for Resource Management, Moscow, ID, November 17-19, 1987; Ferguson, D.E., Morgan, P., Johnson, F.D., Eds.; General Technical Report INT, 257; SAF Publication, 88-06; United States Department of Agriculture, Forest Service, Intermountain Research Station: Ogden, UT, USA, 1989; pp. 90-96.

51. Němeček, J.; Kozák, J. The Czech taxonomic soil classification system and the harmonization of soil maps. In Research Report No. 7; Czech Agricultural University, Department of Soil Science and Geology: Prague, Czech Republic, 2001; pp. 47-53.

52. Hadaš, P. Speciální program pro odvození klimatických dat pro oblast Moravskoslezských Beskyd (The special program for derivation of climatic data for the territory of Moravian-Silesian Beskydy). In Zpravodaj Beskydy: Vliv Imisína Lesy a Lesní Hospodářství Beskyd (The Beskids Bulletin: Influence of Air-Pollution on Forests and Forestry in the Beskids); Tesař, V., Kula, E., Eds.; Mendelova Zemědělská a Lesnická Univerzita v Brně: Brno, Czech Republic, 1997; pp. 229-234. (In Czech)

53. Pyšek, P.; Danihelka, J.; Sádlo, J.; Chrtek, J.J.; Chytrý, M.; Jarošík, V.; Kaplan, Z.; Krahulec, F.; Moravcová, L.; Pergl, J.; et al. Catalogue of alien plants of the Czech Republic (2nd edition): Checklist update, taxonomic diversity and invasion patterns. Preslia 2012, 84, 155-255.

54. Academia. Vegetace České Republiky 4-Lesní a Křovinná Vegetace (Vegetation of the Czech Republic 4. Forest and Scrub Vegetation); Chytrý, M., Ed.; Academia: Praha, Czech Republic, 2013; Volume 4, p. 551, ISBN 978-80-200-2299-8. (In Czech)

55. Ministry of Agriculture of the Czech Republic. Zpráva o Stavu Lesa a Lesniho Hospodářství České Republiky $v$ roce 2013 (Information on Forests and Forestry in the Czech Republic by 2013); Ministry of Agriculture of the Czech Republic: Praha, Czech Republic, 2014; p. 134, ISBN 978-80-7434-153-3. (In Czech)

56. Mack $\dot{u}, \mathrm{~J}$. Methodology for establishing the degree of naturalness of forest stands. Acta Univ. Agric. Silvic. Mendelianae Brun. 2012, 60, 161-166. [CrossRef]

57. Breiman, L. Random forests. Mach. Learn. 2001, 45, 5-32. [CrossRef]

58. Liaw, A.; Wiener, M. Classification and regression by randomForest. $R$ News 2002, 2/3, 18-22.

59. Peck, J.E. Multivariate Analysis for Community Ecologists: Step-By-Step Using PC-ORD; MjM Software: Gleneden Beach, OR, USA, 2010; p. 162, ISBN 0972129022.

60. Lattin, J.M.; Carroll, J.D.; Green, P.E. Analyzing Multivariate Data; Thomson Brooks/Cole: Pacific Grove, CA, USA, 2003; p. 556, ISBN 0534349749.

61. McCune, B.; Mefford, M.J. PC-ORD. Multivariate Analysis of Ecological Data, Version 6.0 for Windows 2011; MjM Software: Gleneden Beach, OR, USA, 2011.

62. Hair, J.F.J.; Hult, T.G.H.; Ringle, C.; Sarstedt, M. A Primer on Partial Least Squares Structural Equation Modeling (PLS-SEM); SAGE Publications, Inc.: Thousand Oaks, CA, USA, 2013; p. 307, ISBN 9781452217444.

63. McCune, B.; Grace, J.B. Analysis of Ecological Communities; MjM Software Design: Gleneden Beach, OR, USA, 2002; p. 300, ISBN 0-9721290-0-6.

64. R Core Team. R: A Language and Environment for Statistical Computing 2014; R Core Team: Vienna, Austria, 2014. 
65. Oksanen, J.; Blanchet, F.G.; Kindt, R.; Legendre, P.; Minchin, P.R.; O’Hara, R.B.; Simpson, G.L.; Solymos, P.; Stevens, M.H.H.; Wagner, H. Vegan: Community Ecology Package. Ordination Methods, Diversity Analysis and Other Functions for Community and Vegetation Ecologists, Version 2.3-4. 2016. Available online: https: / /CRAN.R-project.org/package=vegan (accessed on 22 August 2017).

66. Köppen, W.P. Köppen-Geiger Climate Classification. Available online: http://koeppen-geiger.vu-wien.ac.at/ (accessed on 18 November 2017).

67. Quitt, E. Klimatické Oblasti Československa (Climatic Areas of Czechoslovakia); Studia Geographica 16; Geografický Ústav ČSAV: Brno, Czechoslovakia, 1971; p. 73. (In Czech)

68. Krahulec, F.; Skalova, H.; Herben, T.; Hadincova, V.; Wildova, R.; Pechackova, S. Vegetation changes following sheep grazing in abandoned mountain meadows. Appl. Veg. Sci. 2001, 4, 97-102. [CrossRef]

69. Treml, V.; Jankovská, V.; Petr, L. Holocene dynamics of the alpine timberline in the High Sudetes. Biologia 2008, 63, 73-80. [CrossRef]

70. Novák, J.; Petr, L.; Treml, V. Late-Holocene human-induced changes to the extent of alpine areas in the East Sudetes, Central Europe. Holocene 2010, 20, 895-905. [CrossRef]

71. Kozáková, R.; Šamonil, P.; Kuneš, P.; Novák, J.; Kočár, P.; Kočárová, R. Contrasting local and regional Holocene histories of Abies alba in the Czech Republic in relation to human impact: Evidence from forestry, pollen and anthracological data. Holocene 2011, 21, 431-444. [CrossRef]

72. Elling, W.; Dittmar, C.; Pfaffelmoser, K.; Rötzer, T. Dendroecological assessment of the complex causes of decline and recovery of the growth of silver fir (Abies alba Mill.) in Southern Germany. For. Ecol. Manag. 2009, 257, 1175-1187. [CrossRef]

73. Müllerová, J.; Szabó, P.; Hédl, R. The rise and fall of traditional forest management in southern Moravia: A history of the past 700 years. For. Ecol. Manag. 2014, 331, 104-115. [CrossRef] [PubMed]

74. Müllerová, J.; Hédl, R.; Szabó, P. Coppice abandonment and its implications for species diversity in forest vegetation. For. Ecol. Manag. 2015, 343, 88-100. [CrossRef] [PubMed]

75. Kusbach, A.; Van Miegroet, H.; Boettinger, J.L.; Long, J.N. Vegetation geo-climatic zonation in the rocky mountains, Northern Utah, USA. J. Mt. Sci. 2014, 11, 656-673. [CrossRef]

76. Smith, S.; Davidson, B. User's Manual, Terrestrial Ecological Unit Inventory (TEUI) Land Type Associations, Modoc National Forest; R5-TP; U.S. Department of Agriculture, Forest Service: Washinghton, DC, USA, 2003; p. 268.

77. Nelle, O.; Dreibrodt, S.; Dannath, Y. Combining pollen and charcoal: Evaluating Holocene vegetation composition and dynamics. J. Archaeol. Sci. 2010, 37, 2126-2135. [CrossRef]

78. Robin, V.; Bork, H.-R.; Nadeau, M.-J.; Nelle, O. Fire and forest history of central European low mountain forest sites based on soil charcoal analysis: The case of the eastern Harz. Holocene 2014, 24, 35-47. [CrossRef]

79. Nagel, T.A.; Svoboda, M.; Kobal, M. Disturbance, life history traits, and dynamics in an old-growth forest landscape of southeastern Europe. Ecol. Appl. 2014, 24, 663-679. [CrossRef] [PubMed]

80. Novák, J.; Trotsiuk, V.; Sýkora, O.; Svoboda, M.; Chytrý, M. Ecology of Tilia sibirica in a continental hemiboreal forest, southern Siberia: An analogue of a glacial refugium of broad-leaved temperate trees? Holocene 2014, 24, 908-918. [CrossRef]

81. Rybníček, K.; Rybníčková, E. Pollen analyses of sediments from the summit of the Praděd range in the Hrubý Jeseník Mts (Eastern Sudetes). Preslia 2004, 76, 331-347.

82. Abella, S.R.; Denton, C.W. Spatial variation in reference conditions: Historical tree density and pattern on a Pinus ponderosa landscape. Can. J. For. Res. 2009, 39, 2391-2403. [CrossRef]

83. Novák, J.; Sádlo, J.; Svobodová-Svitavská, H. Unusual vegetation stability in a lowland pine forest area (Doksy region, Czech Republic). Holocene 2012, 22, 947-955. [CrossRef]

84. Novák, J.; Svoboda, J.; Šída, P.; Prostředník, J.; Pokorný, P. A charcoal record of Holocene woodland succession from sandstone rock shelters of North Bohemia (Czech Republic). Quat. Int. 2015, 366, 25-36. [CrossRef]

85. Robin, V.; Talon, B.; Nelle, O. Pedoanthracological contribution to forest naturalness assessment. Quat. Int. 2013, 289, 5-15. [CrossRef]

86. Pokharel, B.; Dech, J.P. An ecological land classification approach to modeling the production of forest biomass. For. Chron. 2011, 87, 23-32. [CrossRef]

87. Pokharel, B.; Dech, J.P. Mixed-effects basal area increment models for tree species in the boreal forest of Ontario, Canada using an ecological land classification approach to incorporate site effects. Forestry 2012, 85, 255-270. [CrossRef] 
88. Bergeron, J.A.C.; Blanchet, F.G.; Spence, J.R.; Volney, W.J.A. Ecosystem classification and inventory maps as surrogates for ground beetle assemblages in boreal forest. J. Plant Ecol. 2012, 5, 97-108. [CrossRef]

89. Meyn, A.; Taylor, S.W.; Flannigan, M.D.; Thonicke, K.; Cramer, W. Relationship between fire, climate oscillations, and drought in British Columbia, Canada, 1920-2000. Glob. Chang. Biol. 2010, 16, 977-989. [CrossRef]

90. Coops, N.C.; Waring, R.H. Estimating the vulnerability of fifteen tree species under changing climate in Northwest North America. Ecol. Model. 2011, 222, 2119-2129. [CrossRef]

91. Haeussler, S. University of Northern British Columbia, Prince George, BC, Canada. Personal communication, 2016.

92. Barbati, A.; Corona, P.; Marchetti, M. A forest typology for monitoring sustainable forest management: The case of European Forest Types. Plant Biosyst. Int. J. Deal. Asp. Plant Biol. 2007, 141, 93-103. [CrossRef]

93. Blasi, C.; Burrascano, S. The role of plant sociology in the study and management of European forest ecosystems. iFor. Biogeosci. For. 2013, 6, 55-58. [CrossRef]

94. Zenner, E.K.; Peck, J.E.; Brubaker, K.; Gamble, B.; Gilbert, C.; Heggenstaller, D.; Hickey, J.; Sitch, K.; Withington, R. Combining Ecological Classification Systems and Conservation Filters Could Facilitate the Integration of Wildlife and Forest Management. J. For. 2010, 108, 296-300.

95. Cameron, R.P.; Williams, D. Completing an Ecosystem Classification System for Nova Scotia. Nat. Areas J. 2011, 31, 92-96. [CrossRef]

96. Peck, J.E.; Zenner, E.K. Site Classification Systems Could Link Social and Ecological Management Constraints. J. For. 2011, 109, 95-100.

97. European Environment Agency. European Forest Types. Categories and Types for Sustainable Forest Management Reporting and Policy; EEA Technical Report; Office for Official Publications of the European Communities: Luxembourg, 2006; p. 111, ISBN 978-92-9167-926-3.

98. European Environment Agency. European Forests—Ecosystem Conditions and Sustainable Use; EEA Report; Office for Official Publications of the European Communities: Luxembourg, 2008; p. 105, ISBN 978-92-9167-354-4.

99. Caudullo, G.; Pasta, S.; Giannetti, F.; Barbati, A.; Chirici, G. European forest classifications. In European Atlas of Forest Tree Species; San-Miguel-Ayanz, J., de Rigo, D., Caudullo, G., Houston Durrant, T., Mauri, A., Eds.; European Commission: Luxembourg, 2016; pp. 32-33.

100. IOS Press. Framework Convention on the Protection and Sustainable Development of the Carpathians (Carpathian Convention); IOS Press: Kyiv, Ukraine, 2003.

101. Ruffini, F.V.; Streifeneder, T.; Eiselt, B. Implementing an International Mountain Convention-An Approach for the Delimitation of the Carpathian Convention Area; EURAC Research: Bolzano, Italy, 2006; p. 119, ISBN 88-99906-20-7.

102. San-Miguel-Ayanz, J.; de Rigo, D.; Caudullo, G.; Houston Durrant, T.; Mauri, A.; Tinner, W.; Ballian, D.; Beck, P.; Birks, H.J.B.; Eaton, E.; et al. European Atlas of Forest Tree Species; European Commission: Luxembourg, 2016; p. 197, ISBN 978-92-79-52833-0.

103. Proctor, J.; Edwards, I.D.; Payton, R.W.; Nagy, L. Zonation of forest vegetation and soils of Mount Cameroon, West Africa. Plant Ecol. 2007, 192, 251-269. [CrossRef]

104. Batkhuu, N.-O.; Lee, D.K.; Tsogtbaatar, J. Forest and Forestry Research and Education in Mongolia. J. Sustain. For. 2011, 30, 600-617. [CrossRef]

105. Rana, M.S.; Samant, S.S.; Rawat, Y.S. Plant communities and factors responsible for vegetation pattern in an alpine area of the northwestern Himalaya. J. Mt. Sci. 2011, 8, 817-826. [CrossRef]

106. Jedrzejek, B.; Drees, B.; Daniëls, F.J.A.; Hölzel, N. Vegetation discontinuities and altitudinal indicator species in mountains of West Greenland: Finding the best positions and traits to observe the impact of climate warming in the Arctic. Appl. Veg. Sci. 2012, 15, 432-448. [CrossRef]

107. Bannister, J.; Donoso, P. Forest Typification to Characterize the Structure and Composition of Old-growth Evergreen Forests on Chiloe Island, North Patagonia (Chile). Forests 2013, 4, 1087-1105. [CrossRef]

108. Laflamme, J.; Munson, A.D.; Grondin, P.; Arseneault, D. Anthropogenic Disturbances Create a New Vegetation Toposequence in the Gatineau River Valley, Quebec. Forests 2016, 7. [CrossRef]

(C) 2017 by the authors. Licensee MDPI, Basel, Switzerland. This article is an open access article distributed under the terms and conditions of the Creative Commons Attribution (CC BY) license (http://creativecommons.org/licenses/by/4.0/). 